\title{
ВЛИЯНИЕ СОСТАВА ЖИДКОЙ И ТВЕРДОЙ ФАЗЫ НА ВЕЛИЧИНУ ОБЪЕМНЫХ ИЗМЕНЕНИИ И ПРОЧНОСТЬ СЛАНЦЕЗОЛЬНОГО ВЯЖУЩЕГО
}

\author{
Е. ГАЛИБИНА, \\ кандидат технических наук \\ Н. ДИЛАКТОРСКИИ, \\ доктор геолого-минералогических наук
}

\section{Л. ТАМM}

Для получения высококачественного строительного материала, изготовленного на основе обычной извести-кипелки, большое значение, как известно, имеет скорость ее гашения [1]. Для увеличения интенсивности этого процесеа в практпке применяются различные ускорители-электролиты, действие которых в основном определяется повышением скорости растворения используемой извести.

Цель нашей работы, с одной стороны, заключалась в установленни влияния раз .тичных химических добавок на скорость гидратации присутствующих в негашеной сланцевой золе $\mathrm{CaO}, \mathrm{CaSO}_{4}$, сбразования гидросульфоалюмината кальция, т. е. процессов, определяюших прочность первичного скелетного сростка: [ $\left.{ }^{2}\right]$. Помимо этого, иззучалось влияние прочности первичного сростка на марку вяжущего в зависимости от вида введенных в состав негашеной золы добавок, что давало возможность научно обосновать целесообразность применения отдельных из ннх в производстве сланцезольных изделий. Исследования состава твердой фазы проходили в тесной связи с исследованиями химиического состава растворов, образующихся в негашеной сланцевой золе, твердеюцей в нормальных условиях.

Для изучения состава истинных растворов, возникающих в пернод схватывания и первоначального отвердевания негашеной сланцевой золы, применялся метод прессфильтрации, подробно описанный нами в 1960 г. [3].

В качесгве исходного для исследований материала были использованы золы фа. кельного сжигания сланца из ТЭЦ-2 г. Кохтла-Ярве, размолотые в шаровой мельнице до удельной поверхности $2500 \mathrm{~cm}^{2} / 2$ (по Товарову). Химический состав этих зол представлен в табл. 1. Степень гидратации окиси кальция и ангидрита определялись термовесовым методом по количеству воды, связанной с этими минералами, а определение уменьшения содержания свободной окиси кальция давало возможность судить о скорости образования гидросульфоалюмината кальция *.

Пластическая прочность образцов исследовалась с помощью коннческого пластометра по методнке, разработанной в МГУ на кафедре коллоидной химии [4].

Испытания механической прочности проводились на лабораторном прессе мощностью 5 тонн на кубиках, изготовленных из сланщезольного теста нормальной консистенцин, размером $2 \times 2 \times 2$ см.

Обьемные изменения в твердеющем в нормальных условиях вяжущем определяли с помощью специально сконструнрованного ртутного волюмометра [5].

* Образованне гидросилнкатов кальцня в золе, твердеющей при $20^{\circ}$, пронсходит крайне медленно. 
Химический состав пылевидных сланцевых зол

\begin{tabular}{|c|c|c|c|c|c|c|c|c|c|c|c|c|c|}
\hline \multirow[b]{2}{*}{$\begin{array}{r}\text { № } \\
\text { ח.11. }\end{array}$} & \multirow[b]{2}{*}{$\begin{array}{l}\text { Вид } \\
\text { золы }\end{array}$} & \multicolumn{12}{|c|}{ В \% (на сухое вещество) } \\
\hline & & $\mathrm{SiO}_{2}$ & $\mathrm{Al}_{2} \mathrm{O}_{3}$ & $\mathrm{Fe}_{2} \mathrm{O}_{3}$ & $\mathrm{CaO}$ & $\mathrm{MgO}$ & $\begin{aligned} & \mathrm{K}_{2} \mathrm{O} \\
+ & \mathrm{Na}_{2} \mathrm{O}\end{aligned}$ & $\mathrm{CO}_{2}$ & $\mathrm{SO}_{3}$ & $\begin{array}{l}\text { Хим. } \\
\text { связ. } \\
\mathrm{H}_{2} \mathrm{O}\end{array}$ & Сумма & $\begin{array}{l}\mathrm{CaO} \\
\text { своб. }\end{array}$ & $\begin{array}{c}\mathrm{SiO}_{2} \\
\text { раств. }\end{array}$ \\
\hline 1. & $\begin{array}{l}\text { Пылевид- } \\
\text { ная слан- } \\
\text { цевая зо- } \\
\text { ла }\left(\mathrm{K}_{51}\right)\end{array}$ & 31,37 & 8,60 & 5,65 & 41,44 & 3,47 & 2,54 & 1,98 & 4,84 & 0,88 & 100,77 & 13,35 & 17,16 \\
\hline 2. & $\begin{array}{l}\text { Пылевид- } \\
\text { ная слан- } \\
\text { цевая зо- } \\
\text { ла }\left(A_{2}\right)\end{array}$ & 29,06 & 7,30 & 5,42 & 46,85 & 2,76 & 2,52 & 1,75 & 2,55 & 1,40 & 100,04 & 23,05 & $\begin{array}{l}\text { не } \\
\text { опред. }\end{array}$ \\
\hline
\end{tabular}

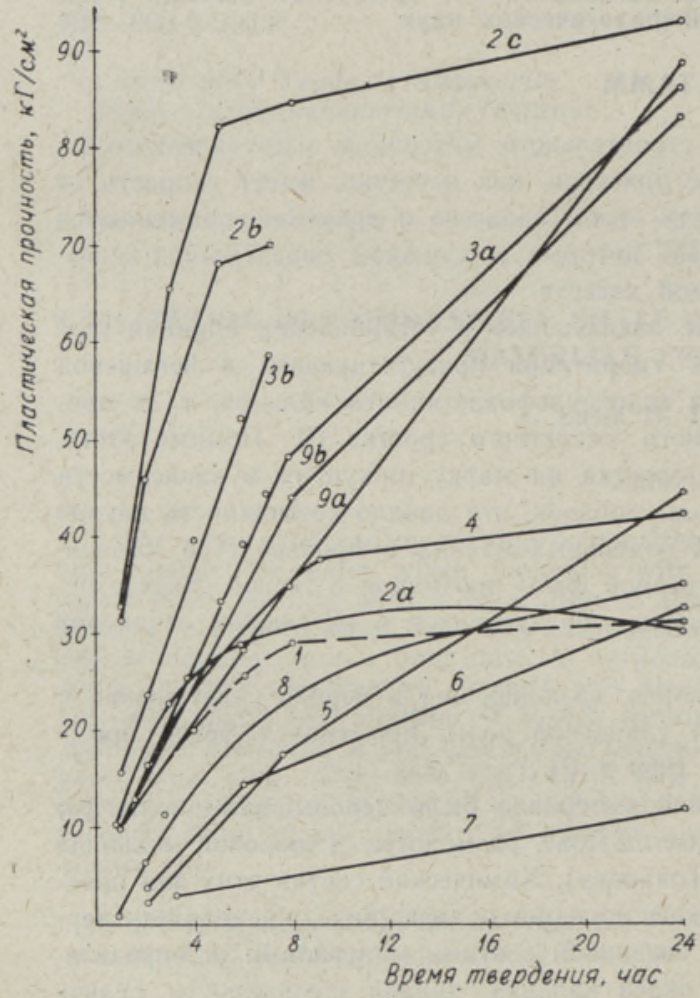

Рнс. 1. Пластическая прочность твердеющей при $20^{\circ}$ негашеной золы в зависимости от состава введенных добавок.

1 - сланцезольное тесто без добавок: $2(a-c)$ - тесто + $1,2,3 \% \mathrm{CaCl}_{2}$; $3(a-b)$ - тесто $+1,3 \% \mathrm{NH}_{4} \mathrm{Cl} ; 4-\mathrm{Te}$ сто $+3 \% \mathrm{CaSO}_{4} \cdot 2 \mathrm{H}_{2} \mathrm{O} ; 5$ - тесто $+5 \%$ $\mathrm{NaCl} ; 6$ - зола затворена на $0,1 \%$-ном растворе глюкозы; 7 - зола затворена на $1 \%$-ном растворе глюкозы; 8 - сланцезольное тесто из смеси гашеной-негашеной золы в соотношении $3: 7 ; 9(a-b)$ - тесто $+1,3 \% \mathrm{NaNO}_{3}$.

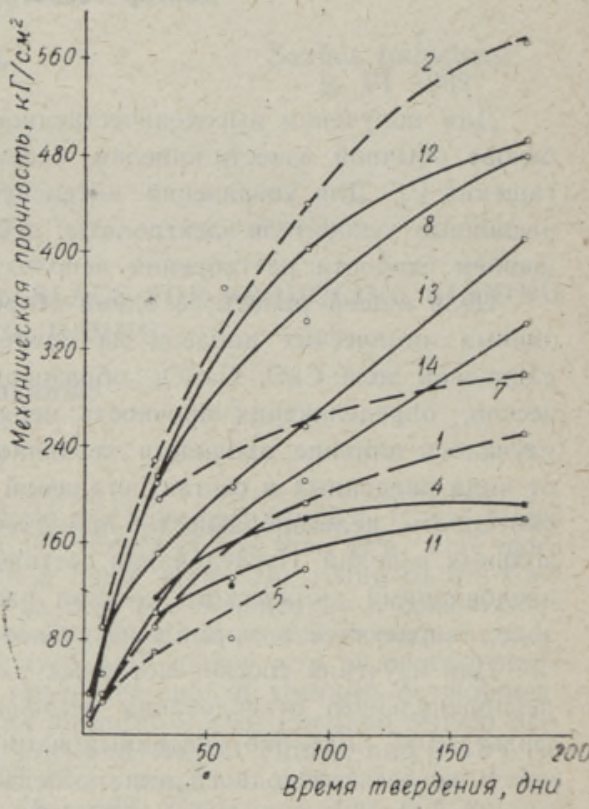

Рис. 2. Механическая прочность твердеюшей при $20^{\circ}$ негашеной золы в зависимости от состава введенных добавок.

1 - сланцезольное тесто золы $\mathrm{A}_{2}$ без добавоқ; 2 - тесто $+3 \% \mathrm{CaCl}_{2} ; 4-$ тесто $+3 \% \mathrm{CaSO}_{4} \cdot 2 \mathrm{H}_{2} \mathrm{O} ; 5$ - зола затворена на $0,5 \%$-ном растворе жидкого стекла; 7 - зола затворена на 0,5\%-ном растворе глюкозы; 8 сланцезольное тесто из смеси гашеной-негашеной золы $(1: 1) ; 11$ тесто $+3 \% \mathrm{NaCl} ; 12,13,14-$ сланцезольное тесто из смеси гашенойнегашеной золы в соотношении соответственно $4: 6 ; 3: 7 ; 1: 9$. 
Растворимые в воде добавки вводились в золу вместе с водой затворения, нерастЕоримые предварительно смешивались с золой. Все исследованные нами добавки, в завнсимости от их влияния на сроки схватывания негашеной сланцевой золы, могут быть разбиты на три группы. Қ первой относятся хлористые соли кальция, магния, аммония, сернокислый кальций, алюминий и другие добавки, в значительной степени сокращающие сроки схватывания негашеной золы. В зависимости от их воздействия на структурно-механнческие свойства твердеющей в нормальных условиях негашеной сланцевой золы, эти добавки, в свою очередь, подразделяются на две подгруппы. К первой относятся хлористые соли кальция, магния, аммония, введение которых способствует sначительному повышению прочности первичного и окончательного сростка (см. рис. 1, кривые $1,2(a-c), 3(a-8)$ и рис. 2 , кривые 1,2$)$.

Вторая подгруппа объеднняет сернокислые соли кальция, алюминия и др., в прнсутствии которых прочность первичного и окончательного сростка практически не увеличивается по сравненню с золой, твердеющей без добавок (см. рис. 1, 2, кривые 1,4).

Ко второй группе относятся добавки, удлиняющие сроки схватывания сланцевой золы. Среди них добавки, содержащие в своем составе ноны $\mathrm{Na}^{\circ}$ или $\mathrm{K}^{*}(\mathrm{NaCl}, \mathrm{KCl}$. $\mathrm{NaSO}_{4}, \mathrm{~K}_{2} \mathrm{SO}_{4}, \mathrm{KOH}, \mathrm{NaOH}$, жидкое стекло), которые не повышают и растворы глюкозы, несколько увеличивающие марку вяжущего (см. рис. 1,2 , кривые $1,5,7,11$ ) Наконец, третью группу представляют собою добавки гашеной золы. Введение их в малых количествах $(10-20 \%)$ практически не изменяет, а в больших (до $50 \%$ ) - не сколько удлиняет сроки схватывания по сравнению с темі, которые имеют место в негашеной золе. Однако как те, так и другие, не повышая прочность первичного сростка, значительно увеличивают марку вяжущего (см. рис. 1 , кривые $l, 9$ и рис. 2 , кри вые $1,8,12,13,14)$.

Рис. 3. Содержание ионов Са“ и $\mathrm{SO}_{4}{ }^{\prime \prime}$ в растворах, образующихся в твердеющей при $20^{\circ}$ золе в зависимости от условий твердения и вида введенных добавок.

$A$ - содержание ионов $\mathrm{Ca}^{*}$ в растворе в пересчете на $\mathrm{CaO}$;

5 - содержание анионов $\mathrm{SO}_{4}^{\prime \prime}$ в растворе в пересчете на $\mathrm{SO}_{3}$.

1 - сланцезольное тесто золы $\mathrm{A}_{2} ; 2$ тесто $+3 \% \quad \mathrm{CaCl}_{2} ; 4$ - тесто $+3 \%$ $\mathrm{CaSO}_{4} \cdot 2 \mathrm{H}_{2} \mathrm{O} ; 5$ - зола $\mathrm{A}_{2}$ затворена на $0,5 \%$-ном растворе жидкого стекла; 7 зола $\mathrm{K}_{\mathrm{c}}$ затворена на $0,5 \%$-ном растворе глюкозы; 8 - сланцезольное тесто из смеси гашеной-негашеной золы $(1: 1) ; 9$ сланцезольное тесто на гашеной золе $\mathrm{A}_{2}$; 10 - тесто $+3 \% \mathrm{NH}_{4} \mathrm{Cl} ; 11$ - тесто $+3 \%$

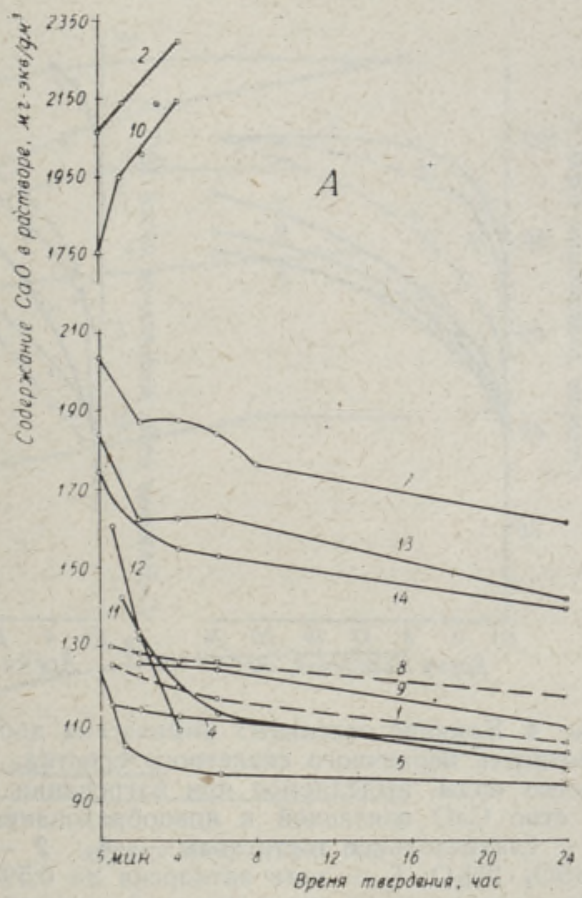

$\mathrm{NaCl} ; 12$ - тесто пропарено при $80^{\circ}$.

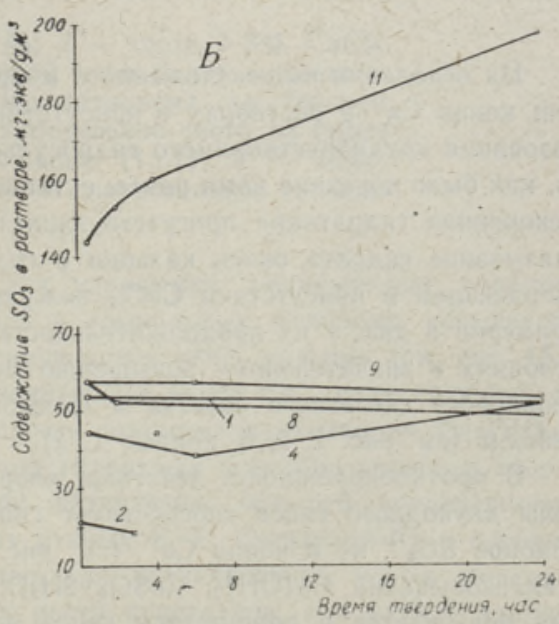


В чем же заключается механизм твердения негашеной золы и каким образом те или. иные добавки, оказывая влияние на прочность первичной структуры, нзменяют прочность вяжущего в дальнейшем?

Наши нсследования показали, что в присутствии добавок первой группы, например $\mathrm{CaCl}_{2}$, концентрация ионов $\mathrm{Ca}^{*}$ в растворе возрастает, а анионов $\mathrm{SO}_{4}{ }^{\prime \prime}$ уменьшается по сравнению с той, которая имеет место в твердеющем без добавок вяжущем (см. рнс. 3 (А, Б), кривые 1,2$)$.

Скорость же выкристаллизовывания гидрата окиси кальция и связывания СаO в новообразования типа гидросульфоалюмината кальция в этих условиях значительно увеличивается. К 30 минутам твердения это ускорение достигает соответственно $1,5-2,5$ раза по сравнению с твердеющей без добавок золой (см. рис. 4 (А-В), кривые 1,2$)$
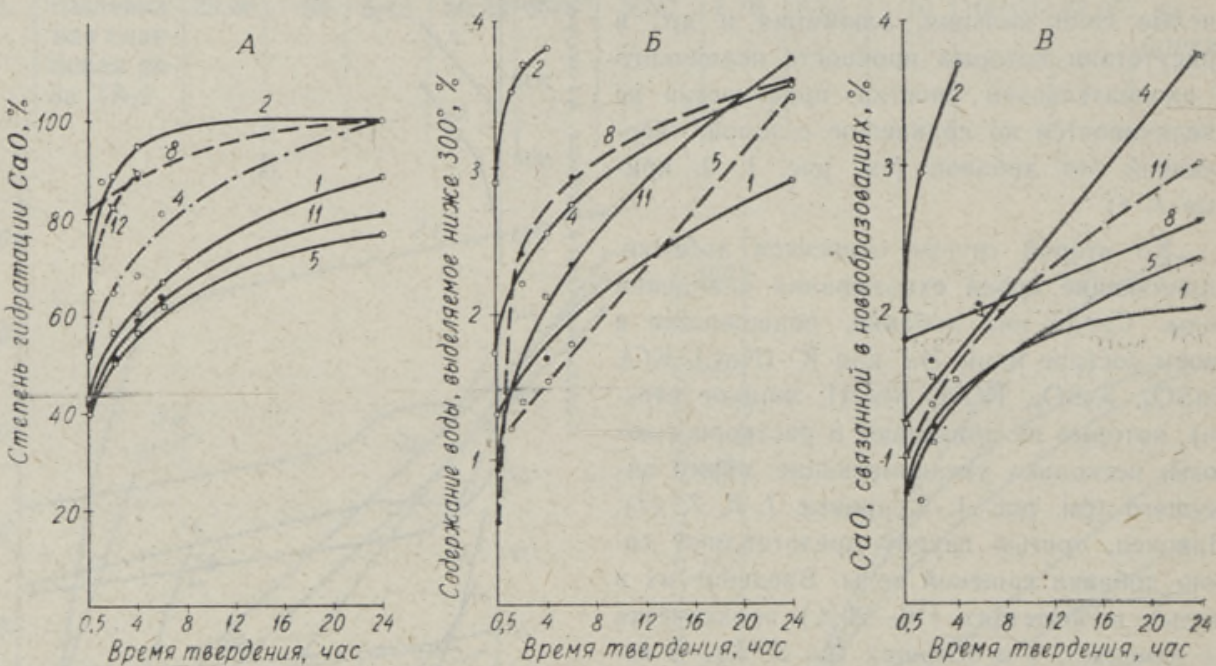

Рис. 4. Влияние отдельных химических добавок на скорость процессов, определяющих прочность первичного скелетного сростка. $A$ - степень гидратации $\mathrm{CaO} ; E-$ количество воды, выделяемое при нагревании пробы в интервале $20-300^{\circ} ; B-$ количество СаO связанной в новообразования типа гидросульфоалюмината кальция. 1 - сланцезольное тесто золы $\mathrm{A}_{2} ; 2-$ тесто $+3 \% \mathrm{CaCl}_{2} ; 4$ - тесто $+3 \%$ $\mathrm{CaSO}_{4} \cdot 2 \mathrm{H}_{2} \mathrm{O} ; 5$ - зола затворена на $0,5 \%$-ном растворе жидкого стекла; 8 - сланцезольное тесто нз смеси гашеной-негашеной золы в соотношении $1: 1 ; 11$ - тесто + $+3 \% \mathrm{NaCl} ; 12$ - тесто пропарено при $80^{\circ}$.

На основании вышеизложенного можно говорить о том, что увеличение концентрацин ионов $\mathrm{Ca}$ “ в растворах в присутствии $\mathrm{CaCl}_{2}$ происходит за счет ускоренного образования труднорастворимого гидросульфоалюмината кальция, в образовании которого, как было показано нами ранее, активное участие принимает гидрат окиси кальция [`] Ускоренная гидратащия присутствующих в золе извести, ангидрита, а также быстрое связывание гидрата окиси кальция в гидросульфоалюминат способствует тому, что в твердеющем в присутствии $\mathrm{CaCl}_{2}$ вяжущем величина объемных изменений снижается примерно в дза, а их продолжительность почти в четыре раза, что и приводит в этих условиях к значительному повышению механической прочности в момент образования первичного скелетного сростка и способствует увеличению марки вяжущего в дальнейшем (см. рис. $1,2,5$, кривые 1,2 ).

В противоположность действню хлористого кальция введение в состав негашеной золы двуводного гипса способствует снижению в растворах концентрации не только анионов $\mathrm{SO}_{4}{ }^{\prime \prime}$, но и ионов Са“ (см. рис. 3 (А, Б), кривые 1,4). Скорость же выкристаллизовывания $\mathrm{Ca}(\mathrm{OH})_{2}, \mathrm{CaSO}_{4} \cdot 2 \mathrm{H}_{2} \mathrm{O}$ и образование гидросульфоалюмината кальция повышается в присутствии гипса по сравнению с твердеющим без добавок, но 
значительно меньше, чем в вяжущем, отвердевающем в присутствии хлористого кальция. Так, например, к 30 минутам твердения в присутствии хлористого кальция и гипса скорость гидратации извести возрастает соответственно в 1,6 и 1,3 раза, а скорость связывания ее в гидросульфоалюминат кальция - в 2,7 и 1,6 раза, по сравнению с золой, отвердевающей без добавок (ем. рис. 4 (А, В), кривые $1,2,4)$. Ускоренная гидратация соединений, определяющих прочность первичной структуры твердения в присутствии добавок гипса, приводит к некоторому уменьшению величины объемных изменений по сравнению с твердеющей без добавок негашеной золой (см. рис. 5, кривые 3,4 ) и некоторому увеличению прочности первичного сростка. Однако продолжительные по времени объемные изменения, развивающиеся в вяжущем в присутствии гипса снияают марку вяжущего (см. рис. $1,2,5$, кривые 1,4 ).

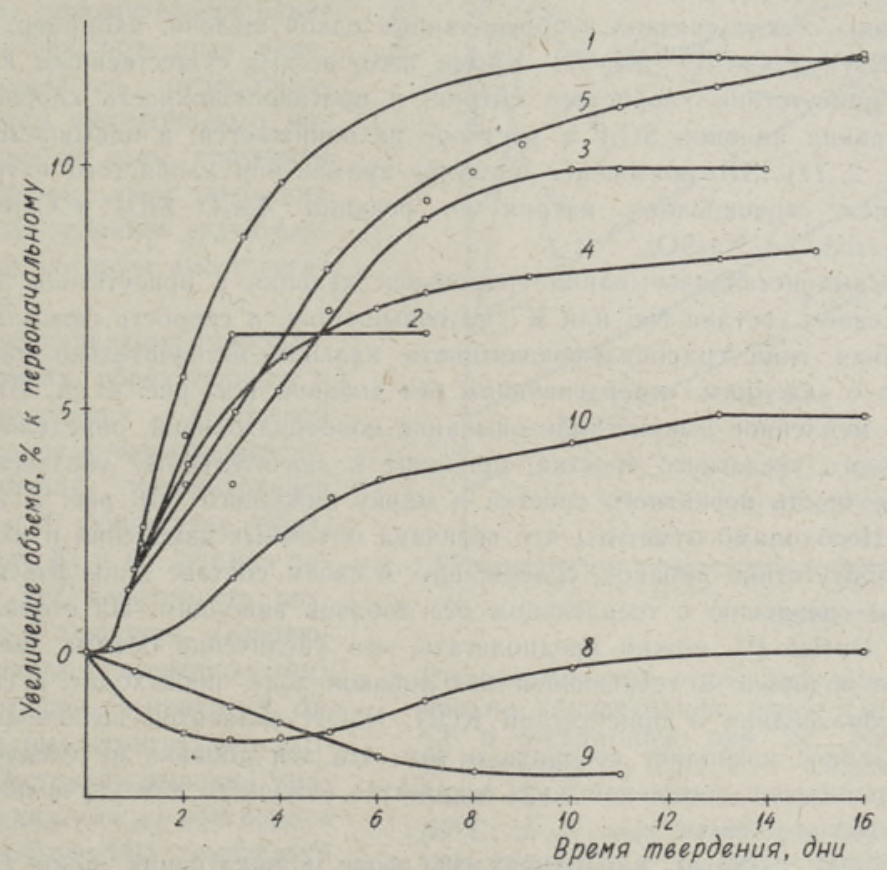

Рис. 5. Влияние химических добавок на величину объемных изменений твердой фазы, в твердеющей при $20^{\circ}$ негашеной золе.

1 - сланцезольное тесто из золы $\mathrm{A}_{2} ; 2$ - тесто $+3 \% \mathrm{CaCl}_{2}$; 3 - сланцезольное тесто из негашеной золы $\mathrm{K}_{51} ; 4$ - тесто + $+3 \% \mathrm{CaSO}_{4} \cdot 2 \mathrm{H}_{2} \mathrm{O} ; 5$ - зола $\mathrm{K}_{51}$ затворена на $5 \%$-ном растворе жидкого стекла; 8 - сланцезольное тесто из смеси гашеной-негашеной золы в соотношении $(1: 1) ; 9-$ сланцезольное тесто на гашеной золе; 10 - сланцезольное тесто из золы $\mathrm{K}_{51}$.

Таким образом, гипс, обычно применяемый для улучшения механических свойств извести-кипелки, не улучшает их в твердеющей в нормальных условиях негашеной золе, в состав которой входит медленно-гидратирующаяся окись кальция (см. рис. 4A, кривая 1). Наконец, рассматривая влияние концентрации ионов Са“, существующей в растворе при добавках $\mathrm{CaCl}_{2}$ и гипса, на скорость выкристаллизовывания $\mathrm{Ca}(\mathrm{OH})_{2}$, $\mathrm{CaSO}_{4} \cdot 2 \mathrm{H}_{2} \mathrm{O}$, можно говорить о том, что переход гидратных новообразований в твердую фазу в присутствии $\mathrm{CaCl}_{2}$ пронсходит при значительно большей концентрацин ионов Са“, чем в присутствни гипса. Исходя из данных Е. Е. Сегаловой [7], в первом случае создаются более благоприятные условия для возникновения новых зародышей (кристаллизационных контактов), чем для роста кристаллов, а в случае приме- 
нения гипса - наоборот, чем и объясняется значительное понижение прочности кри сталлизационной структуры в присутствни гипса по сравнению с $\mathrm{CaCl}_{2}(\mathrm{~cm}$, pнс, 1, 2, крнвые 1,2 ).

Из добавок второй группы, т. е. добавок, замедляющих сроки схватывания негашеной золы, нами исследовалось влияние хлористого натрия, жидкого стекла и растворов глюкозы на прочность первичного и окончательного сростка в твердеющей при $20^{\circ}$ негашеной золе.

В этом случае, в присутствии добавок, содержащих в своем составе ионы $\mathrm{Na}^{\circ}$ и $\mathrm{K}$, отмечалось понижение, а в присутствин глюкозы повышение концентрации ионов Са“ в растворах по сравнению с той, которая имеет место в вяжущем, отвердевающем без добавок (см. рис. 2, 3А, кривые $1,5,7,11$ ).

По нашему мнению, понижение в растворе концентрации ионов Са" в присутствии $\mathrm{NaCl}$ и жидкого стекла связано с образованием едкой щелочи, например, по реакции $\mathrm{Ca}(\mathrm{OH})_{2}+2 \mathrm{NaCl} \rightleftarrows \mathrm{CaCl}_{2}+2 \mathrm{NaOH}$. Кроме того, весьма существенным является тот факт, что в присутствии хлорнстого натрия, в противоположность хлорнстому кальцию, концентрация аннонов $\mathrm{SO}_{4}{ }^{\prime \prime}$ в растворе не понижается, а повышается (см. рис. $3 \mathrm{~B}$, кривые $1,2,11)$. Это повышение в случае применения хлористого натрия связано с образованием сернокислого натрия по реакции $\mathrm{Na}_{2} \mathrm{O} \cdot \mathrm{SiO}_{2}{ }^{*}+\mathrm{CaSO}_{4} \cdot 2 \mathrm{H}_{2} \mathrm{O} \rightarrow$ $\rightarrow \mathrm{CaO} \cdot \mathrm{SiO}_{2} \cdot \mathrm{nH}_{2} \mathrm{O}+\mathrm{Na}_{2} \mathrm{SO}_{4}$.

Скорость выкристаллизовывания гидроокнси кальция в присутствни добавок, содержащих в своем составе $\mathrm{Na}^{\circ}$ или $\mathrm{K}^{*}$, не повышается, а скорость связывания $\mathrm{CaO}$ в новообразования типа гидросульфоалюмината кальция незначительно увеличивается по сравнению с вяжущим, отвердевающим без добавок (см. рис. 4 (А, В), кривые $I$, $5,11)$. Такое медленное выкристаллизовывание новообразований, определяющих прочность первичного скелетного сростка, приводит к значительному увеличению объема II снижает прочнссть первичного сростка и марку вяжущего (см. рис. 1, 2, 5, кривые $1,5,10,11)$. Необходимо отметить, что величина объемных изменений и их продолжнтельность в присутствии добавок, содержащих в своем составе ионы $\mathrm{Na}$ ' или $\mathrm{K}$, увеличивается по сравнению с твердеющим без добавок вяжущим. На основании работ, лроведенных Duriez $\left[{ }^{8}\right]$, можно предполагать, что увеличение объема твердой фазы, превышающее подобное в твердеющей без добавок золе, происходит в связи с возможностью образования в присутствии $\mathrm{KOH}, \mathrm{NaOH}$ силикатов щелочных металлов. Bсе вышесказанное позволяет говорить о том, что эти добавки не следует рекомендовать при примененш негашеной золы в качестве вяжуцего для улучщения ее структурно-механических свойств.

В присутствин глюкозы, как отмечалось выше, концентрация ионов Са“ в растворе повышается за счет того, что скорость выкристаллизовывания гидрата окнси кальция в этих условиях по сравнению с вяжущим, твердеющим без добавок, чрезвычайно мала (см. рис. $2,3 \mathrm{~A}, 4 \mathrm{~A}$, кривые 1,7 ). Однако благодаря повышенной концентрации ионов кальция в растворе в присутствии глюкозы создаются благоприятные условия для возниқновения мелких зародышей, а не для роста кристаллов, что способствует снижению величины объемных изменений и повышенню марки вяжущего (см. рис. 2, кривые 1,7 ).

Наконец, при введении добавок гашеной золы к негашеной (в количестве от 10 до $50 \%$ ), по мере повышення содержания первой, концентрация ионов кальция в растворе повышается, величина объемных изменений сннжается, а марка вяжущего растет (см. рис. 2, кривые $1,8,12-14$ н рис, 5, кривые 1,8 ). Максимальное увеличение марки вяжущего в изученных нами смесях, при твердении негашеной сланцевой золы в нормальных условиях, достигалось при содержании в них 40-50\% предварительно гашеной золы $\left(230 \kappa \Gamma / \mathrm{cm}^{2}\right)$. В этсм случае наблюдалось ускорение процесса гидратации присутствующей в золе окиси кальция и ангидрита, что приводило к значительному уменьшению объема (см. рис. 4 (А, В), 5 , кривые 1, 8). Так, например, в смеси, юдержащей $50 \%$ гашеной золы, скорость гидратации извести была практи-

* Образование силиката натрия возможно в связи с присутствием в золе растворимого кремнезема. 
чески такой же, как и в прнсутствни $\mathrm{CaCl}_{2}$, велнчнна же объемных изменений была значительно ниже, а в первые семь дней твердения в смеси наблюдалась незначительная усадка, около $2 \%$ от первоначального объема (см. рнс. 5 , крнвые $1,2,8$ ). Наши нсследования показали, что усад-

ка была связана с присутствнем в смеси гашеной золы (см. рнс. 5, крнвые $1,8,9$ ). По этой же причнне прочность первичного скелетного сростка в прнсутствни $50 \%$ гашеной золы не превышала прочности его в золе, твердеющей без добавок, т. к. в этом интервале твердения положительное влияние уменьшения объемных нзменений тормозилось отрицательным влнянием значительного количества гашеной золы, прочность которой в первые часы твердения в нормальных условиях значительно ннже той, которую имеет негашеная зола.

Наши исследования показали, что в растворах, образующихся в период твердения негашеной сланцевой золы в нормальных условиях, между концентрацией нонов Са“ и $\mathrm{K}$ “ существует обратная, а между $\mathrm{K}^{*}$ и $\mathrm{Cl}^{\prime}$ прямая зависимость. Эта зависимость сохраняется и в вяжущем, твердеющем в условиях повышенных температур (см. рис. 6, кривые 4, 8).

Необходимо отметить, что ско рость выкристаллизовывания гидрата окиси кальция из раствора в условиях повышенных температур примерно такая же, как и в твердеющем в нормальных условиях вяжущем в присутствии $\mathrm{CaCl}_{2}$ (см. рис. 4A, кривые $1,2,12$ ). ІІринципиальное же отличие в этом случае заключается в том, что при пропарке $\left(80^{\circ}\right)$ этот про-

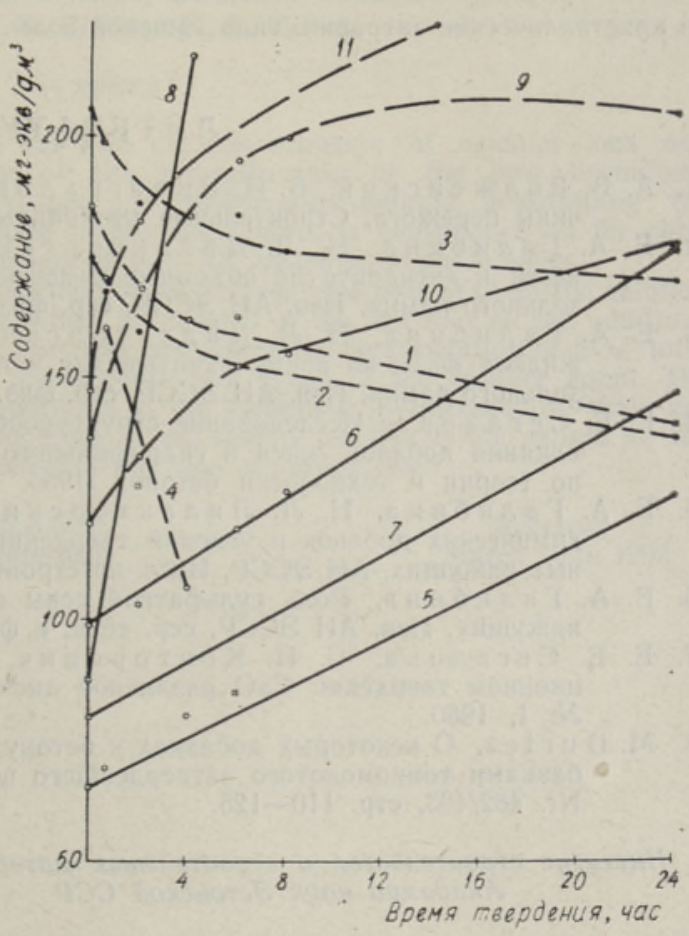

Рнс. 6. Влияние отдельных химических добавок на концентрацию ионов $\mathrm{Ca}^{*}, \mathrm{~K}$, анионов $\mathrm{Cl}^{\prime}$ в твердеющей при $20^{\circ}$ негашеной золе. В пересчете на $\mathrm{CaO}: 1$ - сланцезольное тесто золы $\mathrm{K}_{c} ; 2$ - зола затворена горячей водой $65^{\circ} \mathrm{C} ; 3$ - зола затворена 0,5\%-ным раствором глюкозы; 4 - тесто пропарено при $80^{\circ}$. В пересчете на $\mathrm{K}_{2} \mathrm{O}: 5$ - сланцезольное тесто золы $\mathrm{K}_{c} ; 6$ - зола затворена горячей водой $65^{\circ} ; 7$ - зола затворена $0,5 \%$-ным раствором глюкозы: 8 - зола пропарена при $80^{\circ}$.

В пересчете на $\mathrm{Cl}_{2}: 9$ - сланцезольное тесто золы $\mathrm{K}_{\mathrm{c}} ; 10$ - зола затворена на 0,5\%-ном растворе глюкозы; 11 - зола затворена горячей водой $65^{\circ} \mathrm{C}$.

цесс идет не при повышенной, а

при пониженной концентрации ионов кальция (см. рис. $3 А$, кривые 1,2 и рис. 6, кривую 4). Последняя улучшает условия для роста кристаллов и способствует значительному увеличению объема твердеющей при повышенной температуре негашеной $30 л ы ~\left[{ }^{2}\right]$.

На основании вышеизложенного матернала можно сделать следующие выводы:

1. Қонцентрация ионов кальция в растворе и скорость выкристаллизовывания новообразований: $\mathrm{Ca}(\mathrm{OH})_{2}, \mathrm{CaSO}_{4} \cdot 2 \mathrm{H}_{2} \mathrm{O}$ и гидросульфоалюмината кальция, определяющих прочность первичной структуры, изменяется в широких пределах в зависимости от состава введенных в золу добавок.

2. Между концентрацией ионов кальция в растворе и прочностью первичного сростка существует прямая зависимость, выражающаяся в том, что все добавки, повы- 
шающие концентрацию ионов кальция, уменьшая величину сбъемных изменений, увеличивают прочность первичной структуры и марку вяжущего.

3. Наилучшими добавками, повышающими марку вяжущего в условиях нормального твердения негашеной сланцевой золы, являются добавки $3 \% \mathrm{CaCl}_{2}$ или $\mathrm{NH}_{4} \mathrm{CI}$ и кристаллические затравки типа гашеной золы.

\title{
Л И Т Е РА Т У Р А
}

1. А. В. Волжен ский, Б. Н. Виног радов, Состав пережженой извести и причины пережога, Строительные материалы, № 6, 1961.

2. Е. А. Галиб ин а, Н. Л. Ди лакторски й, Влияние скоростп гидратации извести и ангидрита на объемные изменения и пластическую прочность сланцезольного камня, Изв. АН ЭССР, сер. физ.-матем. и техн. наук, т. Х, № 4, 1961.

3. Е А. Галибина, Н. Л. Дилактор кий, Исследование изменений состава жидкой фазы во время схватывания и первоначального отвердевания сланцезольного камня, Изв. АН ЭССР, сер. физ. матем. и техн, наук, т. IX, № 3, 1960.

4. Е. Е. С ег ал о в а, Исследование структурообразования в цементных суспензиях и влияния добавок гипса и гидрофильного пластифнкатора (С.С.Б.), Тр. совещ. по теории и технологии бетонов, 1956.

5. Е. А. Гали и ина, Н. Л. Лил актор.ский, И. А. Верете вск ая, Влияние химических добавок и условий твердения на объемные пзменения сланцезольных вяжущих, АН ЭССР, Иссл. го строит., $3,1962$.

6. Е. А. Галибина, Роль сульфатной серы в процессе твердения сланцезольных вяжущих, Изв. АН ЭССР, сер. техн. и физ.-матем. наук, т. VI, № 1, 1957.

7. Е. Е. Сегалова, С. И. Конторович, Структурообразование при гидратационном твердении СаO различной дисперсности. Коллоидный журнал, т. 22, № $1,1960$.

8. M. Duri ez, O некоторых добавках к бетону и об ускорении твердения бетона добавками тонкомолотого затвердевшего цемента, Revue les materiaux 1955. Nr. $482 / 483$, стр. $110-125$.

Институт строительства и строительных материалов Академии наук Эстонской ССР
Поступила в редакцию

13. III 1962

\section{VEDELA JA TAHKE FAASI KOOSTISE MOJU KIVINEVA POLEVKIVITUHK- SIDEAINE MAHU MUUTUSTELE}

\author{
E. Galibina, \\ tehnikateaduste kandidaat \\ N. Dilaktorski, \\ geoloogia-mineraloogiateaduste doktor \\ L. Tamm \\ Resümee
}

Käesoleva uurimusega näidatakse, et nii $\mathrm{Ca}{ }^{*}$ - ja $\mathrm{SO}_{4}{ }^{\prime \prime}$-iooni kontsentratsioonist valmistatud lahuses kui ka kaltsiumhüdroksiidist, kipsist ja hüdrosulfoaluminaatidest uusmoodustistes määrab väljakristallumise kiirus tekkiva struktuuri tugevuse, mis muutub laiades piirides, olenevalt kustutamata pôlevkivituhale lisandatud ainete koosseisust.

Lahuses olevate ioonide $\left(\mathrm{Ca}{ }^{~}{ }^{\left.\text {ja } \mathrm{SO}_{4}{ }^{\prime \prime}\right)}\right.$ kontsentratsioon ja tugevus on vastastikuses sōltuvuses: kōik lisandid, mis suurendavad $\mathrm{Ca}$ " ja vähendavad $\mathrm{SO}_{4}^{\prime \prime}$ kontsentratsiooni. vähendavad ka mahumuutusi. Mahumuutuste vähendamine suurendab esialgselt tekkiva struktuuri tugevust ja tōstab sideaine marki,

Parimaiks lisandeiks kustutamata pōlevkivituhale normaalse kivinemise tingimustes on kaltsium- ja ammooniumkloriidid, mida võetakse $3 \%$, ja kustutatud tuhk ise.

Eesti NSV Teaduste Akadeemia

Ehituse ja Ehitusmaterjalide Instituut
Saabus toimetusse

13. III 1962 


\title{
ON THE INFLUENCE OF THE COMPOSITION OF THE LIQUID AND SOLID PHASES
} ON THE VOLUMINAL CHANGES AND STRENGTH OF THE BINDING AGENT

\author{
E. Galibina, N. Dilaktorski, L. Tamm
}

\section{Summary}

In the paper it has been pointed out that the concentration of calcium ions and $\mathrm{SO}_{4}{ }^{\prime \prime}$ in the solution and the velocity of the crystallization of the new formations of the hydrates of calcium oxide, gypsum and hydrosulfoaluminate determining the strength of the initial structure, fluctuate within wide limits in dependence on the composition of the additional materials introduced into the unslaked oil-shale ashes.

There is a relation between the concentration of calcium ions and $\mathrm{SO}_{4}{ }^{\prime \prime}$ in the solution and the strength of the initial structure, which is revealed in the fact that all the additioins increasing the concentration of calcium ions and decreasing the concentration of $\mathrm{SO}_{4}{ }^{\prime \prime}$ ions, reducing voluminal changes, improve the strength and brand of the binding agent. The best of these ingredients, in normal conditions of the hardening of unslaked oil-shale ash are chloride salts of calcium and ammonium in an amount of $3 \%$ of the weight of the binding agent, and crystallized ingredients of the type of slaked ash.

Acadeny of Sciences of the Estonian S.S.R., Institute of Building and Building Materials

Received March 13th, 1962 